\title{
Multiplex ligation dependent probe amplification (MLPA) for rapid distinction between unique sequence positive and negative marker chromosomes in prenatal diagnosis
}

\author{
Diane Van Opstal, Marjan Boter, Petra Noomen, Malgorzata Srebniak, Guus Hamers, Robert-Jan H Galjaard
}

\begin{abstract}
Background: Small supernumerary marker chromosomes (SSMC) are extra structurally abnormal chromosomes that cannot be unambiguously identified with conventional chromosome banding techniques. These marker chromosomes may cause an abnormal phenotype or be harmless depending on different factors such as genetic content, chromosomal origin and level of mosaicism. When a SSMC is found during prenatal diagnosis, the main question is whether the SSMC contains euchromatin since in most cases this will lead to phenotypic abnormalities. We present the use of Multiplex Ligation Dependent probe Amplification (MLPA) for rapid distinction between non-euchromatic and euchromatic SSMC.

Results: 29 well-defined SSMC found during prenatal diagnosis were retrospectively investigated with MLPA with the SALSA MLPA centromere kits P181 and P182 as well as with the SALSA MLPA telomere kits P036B and P070 (MRC Holland BV, Amsterdam, The Netherlands). All unique-sequence positive SSMC were correctly identified with MLPA, whereas the unique-sequence negative SSMC had normal MLPA results.

Conclusions: Although different techniques exist for identification of SSMC, we show that MLPA is a valuable adjunctive tool for rapidly distinguishing between unique-sequence positive and negative SSMC. In case of positive MLPA results, genetic microarray analysis or, if not available, targeted FISH can be applied for further identification and determination of the exact breakpoints, which is important for prediction of the fetal phenotype. In case of a negative MLPA result, which means that the SSMC most probably does not contain genes, the parents can already be reassured and parental karyotyping can be initiated to assess the heritability. In the mean time, FISH techniques are needed for determination of the chromosomal origin.
\end{abstract}

\section{Background}

The finding of a sSMC presents a challenge in prenatal diagnosis particularly for prediction of the clinical consequences which will depend on its genetic content, familial occurrence, level of mosaicism and chromosomal origin [1-5] and parental origin of the SSMC related sister chromosomes [6]. According to the review of Liehr and Weise [7] sSMC are to be expected in $0.075 \%$ of all analysed prenatal cases. In case of fetal ultrasound

\footnotetext{
* Correspondence: a.vanopstal@erasmusmc.nl
Department of Clinical Genetics, Erasmus Medical Centre, PO Box 2040, 3000

* Correspondence: a.vanopstal@erasmusmc.nl
Department of Clinical Genetics, Erasmus Medical Centre, PO Box 2040, 3000 CA Rotterdam, The Netherlands
}

(c) 2011 Van Opstal et al; licensee BioMed Central Ltd. This is an Open Access article distributed under the terms of the Creative

abnormalities this frequency rises to $0.204 \%$, which is $2.7 x$ higher than in the general prenatal population.

Before the introduction of FISH for cytogenetics, identification studies involved the use of classical staining techniques such as GTG, QFQ, Ag-NOR, CBG and DADAPI [1]. Nowadays, different molecular cytogenetic techniques have been developed for identification of sSMC, such as FISH techniques like cenM- and subcenM-FISH $[8,9]$, multicolour banding (MCB)[10], microdissection followed by reverse FISH [11,12], spectral karyotyping (SKY) [13], M-FISH [14] and genomic microarray analysis $[15,16]$. These techniques are expensive and not available in all cytogenetic laboratories [17]. 
In this paper we present the use of Multiplex Ligation Dependent Probe Amplification (MLPA) (MRC Holland, Amsterdam, The Netherlands) as an alternative approach for identification of euchromatic sSMC. On the basis of 29 well characterised SSMC we show that MLPA can rapidly distinguish between unique sequence positive and negative sSMC, which is the most important task when finding a sSMC prenatally. However, other molecular cytogenetic techniques will remain necessary for determining the exact genetic content in case of a positive SSMC, whereas FISH techniques will still be indispensible for identification studies in case of an unique sequence negative sSMC.

\section{Methods}

\section{Samples}

We retrospectively tested the value of MLPA for sSMC identification on 29 well-defined sSMC found during prenatal diagnosis in amniotic fluid $(\mathrm{AF})(\mathrm{n}=26)$ and chorionic villi $(\mathrm{CV})(\mathrm{n}=3)$ (see table 1 and additional file 1). For routine cytogenetics GTG-banding was used in all cases according to standard techniques. Mostly, sSMC identification was done with FISH, sometimes after additional staining with DA-DAPI [18] (see additional file 1). In $23 / 29$ cases the sSMC was present in all investigated cells. In 6/29 cases mosaicism was found in cultured CV or AF cells with the level of mosaicism varying between 30 and $89 \%$ (table 1).

\section{FISH}

Metaphase FISH was performed according to standard techniques. The probes that were used for identification were whole chromosome paints (wcp's)(Kreatech Diagnostics, Ankeveen, The Netherlands and Euro-Diagnostica AB, Nijmegen, The Netherlands), centromere probes (Abbott Molecular Inc., Des Plaines, USA; Resources for Molecular Cytogenetics, Bari, Italy (http://www.biologia.uniba.it/rmc/) and partially received from several investigators), subtelomere-probes [19], locus-specific probes (SNRPN from Cytocell Ltd, Cambridge, UK; LSI TEL AML1 from Abbott Molecular Inc., Des Plaines, USA and others like 102D10 (CES-probe), Y41 and Y11H11 (15q11), r521 (rDNAprobe) were kindly provided by several investigators) and subcentromere-BAC clones that were selected from the University of California Santa Cruz (UCSC) genome browser (http://genome.ucsc.edu) (see additional file 1).

FISH slides were analyzed using the Axioplan 2 Imaging microscope (Zeiss), and images were collected using Isis Software System (Metasystems).

\section{Sample preparation for MLPA and SNP array}

DNA was isolated from $4 \mathrm{ml}$ of uncultured AF or from cultured CV or AF cells. AF cells were cultured by the
Table 129 well-defined SSMC in AF or CV cell cultures that were used in this study

\begin{tabular}{|c|c|c|c|}
\hline Case & sSMC & $\begin{array}{l}\text { Euchromatin (based on } \\
\text { GTG/FISH) }\end{array}$ & $\begin{array}{l}\% \text { of cultured cells } \\
\text { with sSMC }\end{array}$ \\
\hline 1 & $\begin{array}{l}\operatorname{der}(3)(: \text { p12.2- } \\
>\text { cen: })^{2}\end{array}$ & + & 100 \\
\hline 2 & $\begin{array}{l}\min (4)(: p 11- \\
>q 11:)\end{array}$ & - & 100 \\
\hline 3 & psu idic(9)(q12) & + & 87,5 \\
\hline 4 & $\mathrm{i}(12)(\mathrm{p} 10)$ & + & 89 \\
\hline 5 & i(12)(p10) & + & 100 \\
\hline 6 & $\begin{array}{l}\text { neo(12) } \\
\text { (pter->p12.3:) }\end{array}$ & + & 47 \\
\hline 7 & $\begin{array}{l}\operatorname{der}(13) t(4 ; 13) \\
(q 31.3 ; q 13)\end{array}$ & + & 100 \\
\hline 8 & $\min (13$ or 21$)$ & - & 100 \\
\hline 9 & $\min (13$ or 21$)$ & - & 100 \\
\hline 10 & $\begin{array}{l}\operatorname{inv} \operatorname{dup}(14) \\
\text { (q11.2) }\end{array}$ & - & 100 \\
\hline 11 & $\begin{array}{l}\operatorname{der}(14) t(14 ; 16) \\
(q 12 ; q 21)\end{array}$ & + & 100 \\
\hline 12 & $\begin{array}{l}\text { inv dup(15) } \\
\text { (q12) }\end{array}$ & + & 100 \\
\hline 13 & $\begin{array}{l}\text { neo(15)(qtel- } \\
>q 2 ? 4:)^{3}\end{array}$ & + & 100 \\
\hline 14 & $\begin{array}{l}\operatorname{der}(15) t(9 ; 15) \\
(\mathrm{p} 12 ; q 14)\end{array}$ & + & 100 \\
\hline 15 & $\begin{array}{l}\text { inv dup(15) } \\
\text { (q11) }\end{array}$ & - & 100 \\
\hline 16 & $\begin{array}{l}\text { inv dup(15) } \\
\text { (q11.2) }\end{array}$ & - & 100 \\
\hline 17 & $\begin{array}{l}\text { inv dup(15) } \\
\text { (q11.2) }\end{array}$ & - & 100 \\
\hline 18 & $\begin{array}{l}\min (16)(: p 11.1- \\
>\text { q11.1:) }\end{array}$ & - & 30 \\
\hline 19 & $\begin{array}{l}\min (17)(: p 11.1- \\
>\text { q11.1:) }\end{array}$ & - & 45 \\
\hline 20 & $\begin{array}{l}r(20) \\
(q 11.21 q 13.12)\end{array}$ & + & 87 \\
\hline 21 & $\begin{array}{l}\operatorname{inv} \operatorname{dup}(22) \\
(q 11.21)\end{array}$ & + & 100 \\
\hline 22 & $\begin{array}{l}\text { inv dup(22) } \\
\text { (q11.21) }\end{array}$ & + & 100 \\
\hline 23 & $\begin{array}{l}\text { inv dup(22) } \\
\text { (q11.21) }\end{array}$ & + & 100 \\
\hline 24 & $\begin{array}{l}\text { inv dup(22) } \\
\text { (q11.21) }\end{array}$ & + & 100 \\
\hline 25 & $\operatorname{del}(22)(q 11.2)$ & + & 100 \\
\hline 26 & $\begin{array}{l}\operatorname{inv} \operatorname{dup}(22) \\
(q 11.1)\end{array}$ & - & 100 \\
\hline 27 & $\begin{array}{l}\operatorname{inv} \operatorname{dup}(22) \\
(q 11.1)\end{array}$ & - & 100 \\
\hline 28 & $\begin{array}{l}\operatorname{inv} \operatorname{dup}(22) \\
(q 11.1)\end{array}$ & - & 100 \\
\hline 29 & $\begin{array}{l}\text { inv dup (22) } \\
\text { (q11.1) }\end{array}$ & - & 100 \\
\hline
\end{tabular}

${ }^{1}$ For identification details, see additional file $1[38] .{ }^{2}$ This case was previously published by Srebniak et al. [39]. ${ }^{3}$ This case was published earlier by Van Opstal et al. [40]. 
in situ method and CV were cultured using trypsinEDTA and collagenase treatment as described previously [20]. DNA-isolation from uncultured AF cells was done with the Chemagic Magnetic Separation Module I (Chemagen, Baesweiler, Germany). DNA isolation from cultured cells was performed using the QIAamp DNA Mini Kit from Qiagen (Hilden, Germany) or Puregene DNA Purification Kit (Qiagen, Hilden, Germany) according to the manufacturer's instructions.

\section{MLPA-reaction and data analysis}

4 SALSA MLPA kits were used: two centromere kits, P181 and P182, and two telomere-kits, P036B and P070 (http://www.mlpa.com/WebForms/WebFormMain.aspx). Between 20 and 70 ng of DNA was used in a MLPA reaction which was performed on a PCR thermocycler with heated lid (Biometra Thermal Cycler, Westburg, The Netherlands). MLPA reaction and data analysis were performed as described earlier [21]. In order to enable the detection of chromosomal mosaicism as was seen in 6/29 cases, we calculated own cut off values (median $\pm 2 x$ SD) for the different probes on the different chromosomes for all four MLPA-kits on the basis of 95 (P181), 91 (P182), 104 (P036B) and 105 (P070) normal samples (see table 2).

\section{SNP array, data analysis and interpretation}

In two cases (cases 13 and 25) a SNP array (HumanCytoSNP-12, Illumina) was performed because of discrepancies between the results of GTG/FISH and MLPA. 200 ng of DNA isolated from cultured cells was used in both cases. DNA amplification, tagging and hybridisation were performed according to the manufacturer's protocol. Array slides were scanned on the iScan Reader (Illumina). Data analysis was performed using Genome Studio version 2010.1 (Illumina). The HapMap control set provided by the manufacturer was used as a control.

\section{Results}

\section{Unique sequence positive sSMC}

All unique sequence positive sSMC (Table 1) were correctly identified with MLPA with the centromere kits (cases 1 and 20), telomere kits (cases 6 and 13) or both (cases 3-5, 7, 11, 12, 14, 21-25) (see table 3) confirming GTG/FISH results. There were no false negative cases.

\section{a. Non-mosaic cases}

The relative probe signals in most non-mosaic cases (see table 1) correctly discriminated between 3 and 4 copies of the investigated probes, with relative probe signals $>$ 1.3 and $<1.5$ for a trisomy and $>1.6$ for a tetrasomy (see table 3 ). In $3 / 23$ non-mosaic cases a discrepancy was found.

Case 1: Although amplification of EPHA3 confirmed the results of FISH and DNA marker studies (sSMC=der(3) (:p12.2->cen:) in case 1, the relative probe signals of the 3p11.2 marker EPHA3 in both centromere-kits were not above 1.3 (1.178 in P181 and 1.226 in P182) as would be expected in a full blown case. However, they were clearly above the normal cut off value of 1.077 for both kits probably indicating loss of the sSMC in part of the cells and therefore mosaicism at the time that DNA for MLPA was isolated from the cell cultures.

Case 13 showed a full blown neo(15) in cultured AF cells (8 cell clones investigated) (see Figure 1a), which is an analphoid sSMC with a neocentromere and consisting of two copies of the distal end of chromosome 15q. However, the relative probe signals of the $15 \mathrm{q}$-subtelomere probes were only 1.45 and 1.428 in respectively P036B and P070, indicative of a trisomy but not a tetrasomy as expected (Figure $1 \mathrm{~b}$ ).

In order to elucidate this discrepancy, genomic microarray analysis was performed. Investigations with the HumanCytoSNP-12 indicate that this case is more complex than initially thought which may explain the MLPA results. Based on Log $\mathrm{R}$ ratio and $\mathrm{B}$-allele frequency (BAF), we expect mosaicism of different abnormal cell lines containing different sSMC. However, BAF's of 0,1 , 0.333 and 0.667 and absence of a BAF of 0.5 at 15 q26.3 (in contrast to the region 15q24.1-q26.2) indicate a trisomy at 15 qtel which confirms the MLPA results (see Figure 1c).

In case 25 of an extra familial del(22)(q11.2) the results of MLPA with the $22 \mathrm{q} 11$ probes in the four kits were indicative for 4 copies of this chromosomal region: relative probe signals were 1.770 and 1.621 (P181), 1.760 and 1.869 (P182), 1.688 (P036B) and 1.806 (P070) (Figure $2 \mathrm{~b}$ ). This contradicts the FISH results with one signal on the sSMC for two different 22cen-probes, one for the rDNA-probe and one signal with the probe from the Cat Eye Syndrome (CES)-region (Figure 2a). HumanCytoSNP-12-analysis confirmed the sSMC to be at least a partial duplication of chromosome 22, indicated by a BAF of 0.5 , resulting in 4 copies of the sequences detected by the proximal 22q-probes in the 4 MLPA kits (Figure 2c).

\section{b. Mosaic cases}

In one out of four mosaic cases (case 3), MLPA correctly identified four copies of 9ptel (P070, P036B), 9p11 (p182) and 9p13.2 (P181) with relative probe signals > 1.6 (table 3). However, in three out of four mosaic cases (cases 4, 6 and 20), the relative probe signals of some probes were below the expected values (1.3 for a trisomy and 1.6 for a tetrasomy). In these cases, the level of mosaicism, which was determined in cultured AF cells, was unknown in uncultured AF cells from which the DNA for MLPA was isolated. Nevertheless, the sSMC in all three cases could be identified by making use of our 
Table 2 Cut off values (median probe signal \pm 2 SD) for the different probes in the MLPA kits P181, P182, P036B and P070

\begin{tabular}{|c|c|c|c|c|c|}
\hline \multirow[t]{2}{*}{ Probes P181 } & \multicolumn{2}{|c|}{ Cut off values $(\mathrm{N}=95)$} & \multirow[t]{2}{*}{ Probes $\mathrm{P} 182$} & \multicolumn{2}{|c|}{ Cut off values $(\mathrm{N}=91)$} \\
\hline & Minimum & Maximum & & Minimum & Maximum \\
\hline $3 p 11.2$ EPHA3 & 0,923 & 1,077 & 3p11.2 EPHA3 & 0,923 & 1,077 \\
\hline 3q11.2 PROS1 & 0,907 & 1,093 & $3 q 11.2$ PROS1 & 0,913 & 1,087 \\
\hline 4p11 OCIAD1 & 0,880 & 1,114 & 4p11 OCIAD1 & 0,880 & 1,114 \\
\hline $4 q 12$ SGCB & 0,946 & 1,054 & $4 q 12$ USP46 & 0,919 & 1,081 \\
\hline 9p13.2 IGFBPL1 & 0,902 & 1,098 & 9p11 EXOSC3 & 0,940 & 1,060 \\
\hline $9 q 13$ TJP2 & 0,933 & 1,067 & 9q13 TJP2 & 0,909 & 1,079 \\
\hline 12p11.21 PKP2 & 0,888 & 1,112 & 12p11.21 PKP2 & 0,894 & 1,090 \\
\hline $12 q 12 \mathrm{KIF} 21 \mathrm{~A}$ & 0,899 & 1,101 & $12 q 12 \mathrm{KIF} 21 \mathrm{~A}$ & 0,886 & 1,114 \\
\hline 13q11 HSMPP8 & 0,881 & 1,119 & $13 q 11$ HSMPP8 & 0,924 & 1,060 \\
\hline 13q11 ZNF198 & 0,930 & 1,066 & $13 q 11$ ZNF198 & 0,881 & 1,119 \\
\hline 14q11.2 ADPRTL2 & 0,863 & 1,115 & 14q11.2 ADPRTL2 & 0,913 & 1,079 \\
\hline 14q11.2 APEX & 0,917 & 1,083 & 14q11.2 APEX & 0,932 & 1,066 \\
\hline 15q11.2 NIPA2 & 0,883 & 1,097 & 15q11.2 NIPA2 & 0,864 & 1,128 \\
\hline $15 q 11.2 \mathrm{NDN}$ & 0,916 & 1,078 & $15 q 11.2$ MKRN3 & 0,874 & 1,126 \\
\hline 16p11.2 TGFB1I1 & 0,882 & 1,098 & 16p11.2 ERAF & 0,927 & 1,071 \\
\hline 16q12 ORC6L & 0,914 & 1,086 & $16 q 12$ VPS35 & 0,899 & 1,101 \\
\hline 17p11.2 MAP2K3 & 0,934 & 1,064 & 17p11.2 MAP2K3 & 0,828 & 1,170 \\
\hline 17q11.1 WSB1 & 0,927 & 1,073 & 17q11.1 WSB1 & 0,931 & 1,069 \\
\hline 20p11.2 PYGB & 0,894 & 1,102 & 20p11.21 ZNF337 & 0,914 & 1,086 \\
\hline 20q11.21 DUSP15 & 0,912 & 1,088 & 20q11.21 REM1 & 0,893 & 1,075 \\
\hline 21q11 STCH & 0,911 & 1,089 & $21 \mathrm{q} 11 \mathrm{STCH}$ & 0,896 & 1,104 \\
\hline 21q11 SAMSN1 & 0,861 & 1,153 & 21q11 SAMSN1 & 0,889 & 1,111 \\
\hline 22q11.2 CECR5 & 0,872 & 1,086 & $22 q 11.2$ CECR1 & 0,877 & 1,083 \\
\hline 22q11.2 CECR1 & 0,901 & 1,089 & 22q11.2 SLC25A18 & 0,916 & 1,084 \\
\hline \multirow[t]{2}{*}{ Probes P036B } & \multicolumn{2}{|c|}{ Cut off values $(N=104)$} & Probes P070 & \multicolumn{2}{|c|}{ Cut off values $(\mathrm{N}=105)$} \\
\hline & Minimum & Maximum & & Minimum & Maximum \\
\hline $3 p$ CHL1 & 0.890 & 1.110 & $3 p$ CHL1 & 0.916 & 1.080 \\
\hline $3 q \mathrm{BDH}$ & 0.905 & 1.092 & $3 q$ KIAA0226 & 0.933 & 1.067 \\
\hline 4p FLJ20265 & 0.900 & 1.101 & $4 p$ ZNF141 & 0.828 & 1.172 \\
\hline 4q FRG1 & 0.744 & 1.239 & 4q FRG1 & 0.865 & 1.143 \\
\hline 9p DMRT1 & 0.897 & 1.103 & 9p FLJ00026 & 0.915 & 1.083 \\
\hline 9q MRPL41 & 0.847 & 1.148 & 9q EU-HMTase1 & 0.935 & 1.065 \\
\hline 12p SLC6A12 & 0.947 & 1.053 & 12p RBBP2 & 0.937 & 1.063 \\
\hline 12q ZNF10 & 0.858 & 1.126 & $12 \mathrm{q}$ ZNF10 & 0.909 & 1.091 \\
\hline 13p PSPC1 & 0.914 & 1.074 & $13 p$ PSPC1 & 0.900 & 1.116 \\
\hline $13 q \mathrm{~F} 7$ & 0.883 & 1.116 & $13 q \mathrm{CDC} 16$ & 0.923 & 1.073 \\
\hline 14p HEI10 & 0.919 & 1.081 & 14p ADPRTL2 & 0.929 & 1.071 \\
\hline 14q MTA1 & 0.859 & 1.143 & 14q MTA1 & 0.906 & 1.094 \\
\hline 15p CYFIP1 & 0.925 & 1.075 & $15 p \mathrm{NDN}$ & 0.908 & 1.092 \\
\hline 15q ALDH1A3 & 0.890 & 1.110 & $15 q$ FLJ22604 & 0.938 & 1.062 \\
\hline 16p POLR3K & 0.894 & 1.108 & 16p DECR2 & 0.828 & 1.178 \\
\hline 16q GAS11/GAS8 & 0.894 & 1.106 & $16 q$ GAS11 & 0.936 & 1.060 \\
\hline 17p RPH3AL & 0.901 & 1.099 & 17p RPH3AL & 0.843 & 1.163 \\
\hline $17 q \mathrm{TBCD}$ & 0.888 & 1.108 & 17q SECTM1 & 0.890 & 1.096 \\
\hline $20 p$ sox12 & 0.843 & 1.157 & 20p FLJ22115 & 0.888 & 1.112 \\
\hline 20q OPRL1 & 0.866 & 1.134 & 20q FLJ20517 & 0.883 & 1.117 \\
\hline 21p RBM11 & 0.879 & 1.121 & $21 p$ STCH & 0.894 & 1.132 \\
\hline 21q HMT1 & 0.853 & 1.147 & $21 \mathrm{q}$ S100B & 0.921 & 1.065 \\
\hline $22 p$ BID & 0.894 & 1.094 & 22p IL17R & 0.837 & 1.163 \\
\hline 22q RABL2B & 0.875 & 1.127 & $22 q$ ARSA & 0.904 & 1.096 \\
\hline
\end{tabular}

Only the chromosomes from which the SSMC in this paper are derived, are indicated. 
Table 3 MLPA results of 16 prenatal cases with a unique sequence positive sSMC

\begin{tabular}{|c|c|c|c|c|c|c|c|c|c|c|}
\hline \multirow[t]{3}{*}{ No } & \multirow[t]{3}{*}{ sSMC } & \multirow[t]{3}{*}{$\begin{array}{l}\text { DNA source } \\
\text { for MLPA }\end{array}$} & \multicolumn{8}{|c|}{$\begin{array}{l}\text { MLPA-results: copy number of sequence(s) in the kit, genes that they target and their abnormal } \\
\text { relative probe signal(s) }\end{array}$} \\
\hline & & & \multicolumn{2}{|r|}{ P181 } & \multicolumn{2}{|r|}{ P182 } & \multicolumn{2}{|r|}{ P036B } & \multicolumn{2}{|r|}{ P070 } \\
\hline & & & $\begin{array}{l}\text { Copy } \\
\text { numb. }\end{array}$ & $\begin{array}{l}\text { Relative probe } \\
\text { signal(s) }\end{array}$ & $\begin{array}{l}\text { Copy } \\
\text { numb. }\end{array}$ & $\begin{array}{l}\text { Relative probe } \\
\text { signal(s) }\end{array}$ & $\begin{array}{l}\text { Copy } \\
\text { numb. }\end{array}$ & $\begin{array}{l}\text { Relative probe } \\
\text { signal(s) }\end{array}$ & $\begin{array}{l}\text { Copy } \\
\text { numb. }\end{array}$ & $\begin{array}{l}\text { Relative probe } \\
\text { signal(s) }\end{array}$ \\
\hline & $\frac{\text { Mosaic }}{\underline{\text { cases }}^{1}}$ & & & & & & & & & \\
\hline 3 & $\begin{array}{l}\text { psu idic(9) } \\
\text { (q12) } \\
(87,5 \%)\end{array}$ & LTC-CV & 4 & IGFBPL1: 2.046 & 4 & EXOSC3: 1.9013 & 4 & DMRT1: 1.854 & 4 & FLJ00026: 1.835 \\
\hline 4 & $\begin{array}{l}i(12)(\mathrm{p} 10) \\
(89 \%)\end{array}$ & UAF & 4 & PKPR2: $1.577^{2}$ & 4 & PKP2: $1.520^{2}$ & 4 & SLC6A12: 1.718 & 4 & RBBP2: 1.602 \\
\hline 6 & $\begin{array}{l}\text { neo(12) } \\
\text { (pter->p12.3:) } \\
(47 \%)\end{array}$ & UAF & 2 & $\begin{array}{l}\text { PKPR2: } 1.006 \\
\text { KIF21A: } 1.015\end{array}$ & 2 & $\begin{array}{l}\text { PKP2: } 1.016 \\
\text { KIF21A: } 1.045\end{array}$ & 4 & SLC6A12: 1.765 & 4 & RBBP2: $1.519^{2}$ \\
\hline \multirow[t]{2}{*}{20} & $\begin{array}{l}r(20) \\
(q 11.21 q 13.12) \\
(87 \%)\end{array}$ & UAF & 3 & DUSP15: 1.461 & 3 & REM1: $1.183^{3}$ & 2 & $\begin{array}{l}\text { SOX12:1.088 } \\
\text { OPRL: } 1.000\end{array}$ & 2 & $\begin{array}{l}\text { FLJ22115: } 0.989 \\
\text { FLJ20517: } 1.004\end{array}$ \\
\hline & $\frac{\text { Non-mosaic }}{\text { cases }}$ & & & & & & & & & \\
\hline 1 & $\begin{array}{l}\operatorname{der}(3) \\
(: p 12.2->\text { cen: })\end{array}$ & LTC-CV & 3 & EPHA3: $1.178^{3}$ & 3 & EPHA3: $1.226^{3}$ & 2 & CHL1: 0.974 & 2 & CHL1: 0.965 \\
\hline 5 & i(12)(p10) & UAF & 4 & PKPR2: 1.632 & 4 & PKP2: 1.795 & 4 & SLC6A12: 1.645 & 4 & RBBP2: 1.699 \\
\hline 7 & $\begin{array}{l}\text { der(13)t(4;13) } \\
\text { (q31.3;q13) }\end{array}$ & CAF & 3 & $\begin{array}{l}\text { HSMPP8: } 1.470 \\
\text { ZNF198: } 1.322\end{array}$ & 3 & $\begin{array}{l}\text { HSMPP8:1.387 } \\
\text { ZNF198: } 1.534\end{array}$ & 3 & $\begin{array}{l}\text { PSPC1: } 1.352 \\
\text { FRG1: } 1.235^{4}\end{array}$ & 3 & $\begin{array}{l}\text { PSPC1:1.495 } \\
\text { FRG1: } 1.300\end{array}$ \\
\hline 11 & $\begin{array}{l}\operatorname{der}(14) t(14 ; 16) \\
(q 12 ; q 21)\end{array}$ & $\mathrm{CAF}$ & 3 & $\begin{array}{l}\text { APEX: } 1.358 \\
\text { ADPRTL2:1.310 }\end{array}$ & 3 & $\begin{array}{l}\text { ADPRTL2: } 1.371 \\
\text { APEX: } 1.410\end{array}$ & 3 & $\begin{array}{l}\text { HEl10: } 1.393 \\
\text { GAS11/GAS8: } \\
1.498\end{array}$ & 3 & $\begin{array}{l}\text { ADPRTL2: } 1.462 \\
\text { GAS11: } 1.381\end{array}$ \\
\hline 12 & $\begin{array}{l}\text { inv dup(15) } \\
\text { (q12) }\end{array}$ & $\mathrm{CAF}$ & 4 & $\begin{array}{l}\text { NDN: } 1.702 \\
\text { NIPA2: } 1.770\end{array}$ & 4 & $\begin{array}{l}\text { MKRN3: } 1.635 \\
\text { NIPA2: } 1.851\end{array}$ & 4 & CYFIP1: 1.714 & 4 & NDN: 1.668 \\
\hline 13 & $\begin{array}{l}\text { neo(15) } \\
\text { (qtel->q2?4:) }\end{array}$ & CAF & 2 & $\begin{array}{l}\text { NDN: } 1.007 \\
\text { NIPA2: } 0.932\end{array}$ & 2 & $\begin{array}{l}\text { MKRN3: } 0.879 \\
\text { NIPA2: } 1.087\end{array}$ & 3 & ALDH1A3: 1.450 & 3 & FLJ22604: 1.485 \\
\hline 14 & $\begin{array}{l}\operatorname{der}(15) t(9 ; 15) \\
(p 12 ; q 14)\end{array}$ & UAF & 3 & $\begin{array}{l}\text { NDN: } 1.324 \\
\text { NIPA2: } 1.406 \\
\text { IGFBPL1: } 1.401\end{array}$ & 3 & $\begin{array}{l}\text { MKRN3: } 1.493 \\
\text { NIPA2: } 1.335 \\
\text { EXOSC3: } 1.314\end{array}$ & 3 & $\begin{array}{l}\text { CYFIP1: } 1.424 \\
\text { DMRT1: } 1.455\end{array}$ & 3 & $\begin{array}{l}\text { NDN: } 1.324 \\
\text { FLJ00026: } \\
1.820^{5}\end{array}$ \\
\hline 21 & $\begin{array}{l}\text { inv dup(22) } \\
\text { (q11.21) }\end{array}$ & CAF & 4 & $\begin{array}{l}\text { CECR1: } 1.831 \\
\text { CECR5: } 1.572^{6}\end{array}$ & 4 & $\begin{array}{l}\text { CECR1: } 1.830 \\
\text { SLC25A18: } 1.773\end{array}$ & 4 & BID: 1.825 & $3^{6}$ & IL17R: 1.548 \\
\hline 22 & $\begin{array}{l}\text { inv dup(22) } \\
\text { (q11.21) }\end{array}$ & UAF & 4 & $\begin{array}{l}\text { CECR1: } 1.789 \\
\text { CECR5: } 1.654\end{array}$ & 4 & $\begin{array}{l}\text { CECR1: } 1.796 \\
\text { SLC25A18: } 1.811\end{array}$ & 4 & BID: 1.907 & 4 & IL17R: 1.881 \\
\hline 23 & $\begin{array}{l}\operatorname{inv} \operatorname{dup}(22) \\
\text { (q11.21) }\end{array}$ & UAF & 4 & $\begin{array}{l}\text { CECR1: } 1.694 \\
\text { CECR5: } 1.724\end{array}$ & 4 & $\begin{array}{l}\text { CECR1: } 1.711 \\
\text { SLC25A18: } 1.691\end{array}$ & 4 & BID: 1.940 & 4 & IL17R: 2.080 \\
\hline 24 & $\begin{array}{l}\text { inv dup(22) } \\
\text { (q11.21) }\end{array}$ & CAF & 4 & $\begin{array}{l}\text { CECR1: } 1.840 \\
\text { CECR5: } 1.819\end{array}$ & 4 & $\begin{array}{l}\text { CECR1: } 1.790 \\
\text { SLC25A18: } 2.098\end{array}$ & 4 & BID: 1.693 & $3^{6}$ & IL17R: 1.527 \\
\hline 25 & $\begin{array}{l}\text { del(22) } \\
\text { (q11.2) }\end{array}$ & LTC-CV & 4 & $\begin{array}{l}\text { CECR1: } 1.770 \\
\text { CECR5: } 1.621\end{array}$ & 4 & $\begin{array}{l}\text { CECR1: } 1.760 \\
\text { SLC25A18: } 1.869\end{array}$ & 4 & BID: 1.688 & 4 & IL17R: 1.806 \\
\hline
\end{tabular}

LTC-CV = long-term cultured chorionic villi; uAF = uncultured amniotic fluid cells; CAF = cultured amniotic fluids cells.

': Level of mosaicism was determined in cultured cells, whereas DNA from uncultured cells was used for MLPA in cases 4, 6 and 20.

2: Although relative probe signals indicate 3 copies $(<1.6)$ we interpreted these results as 4 copies because of mosaicism in the cell cultures.

${ }^{3}$ relative probe signal is clearly above the normal cut off value but $<1.3$, probably indicating mosaicism.

${ }^{4}$ the relative probe signal of 4 qtel probe (FRG1) is in fact below the cut off value of 1.239 . The FRG1 specific probes in the P036 kits were found not to be reliable by the manufacturer due to the presence of population specific SNP's in FRG1 (see website of MRC-Holland).

${ }^{5}$ The probe for $9 p$ in the P070 kit was found to be duplicated in some healthy individuals (see MRC Holland-website) which may explain the relative probe signal of 1.820 indicating 4 instead of 3 copies of 9 ptel.

${ }^{6}$ The relative probe signal of the sequence targeting CECR5 in case 21 and IL17R in cases 21 and 24 is $<1.6$ and therefore indicating 3 instead of 4 copies. However, on the basis of the relative probe signals of the other probes in the same and/or other kits, we assume the presence of 4 copies of CECR5 and/or IL17R on the SSMC in cases 21 and 24 
A
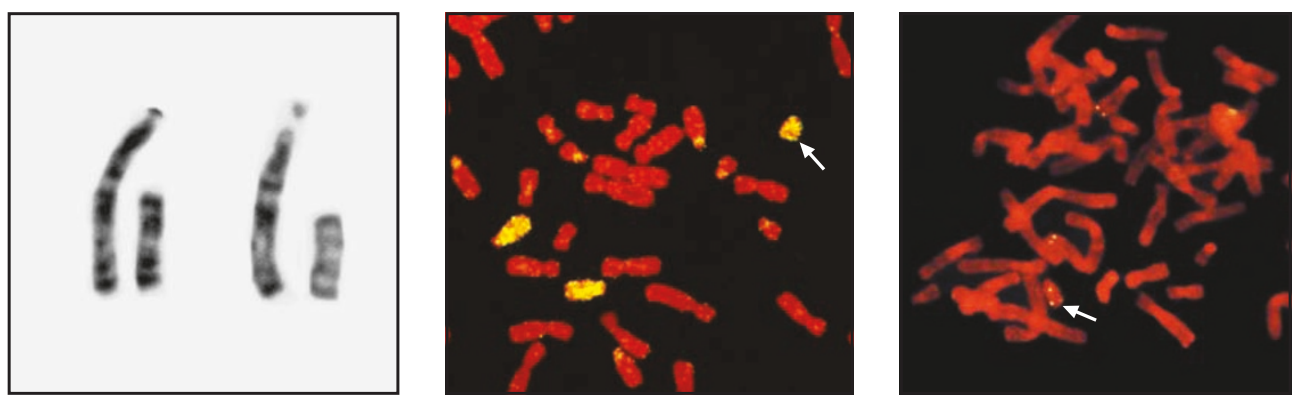

B
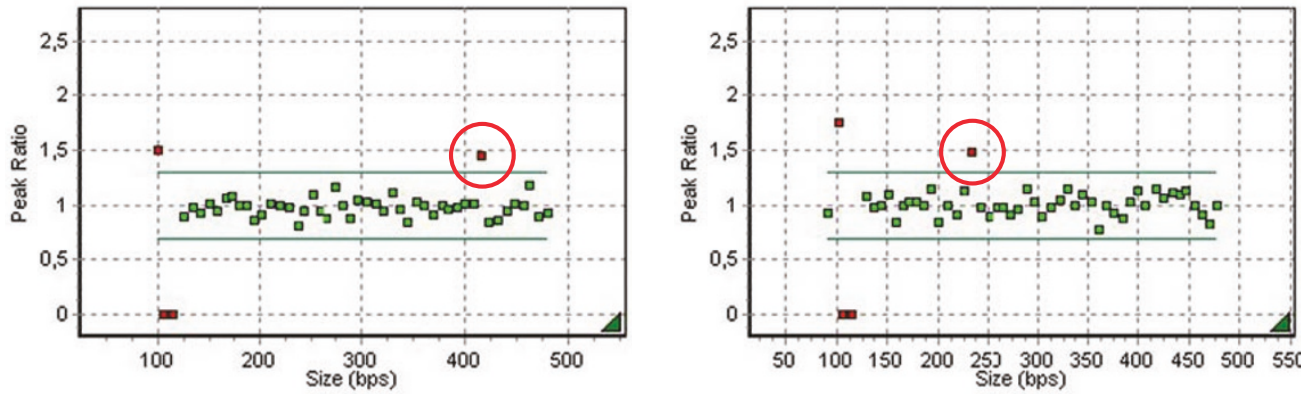

C

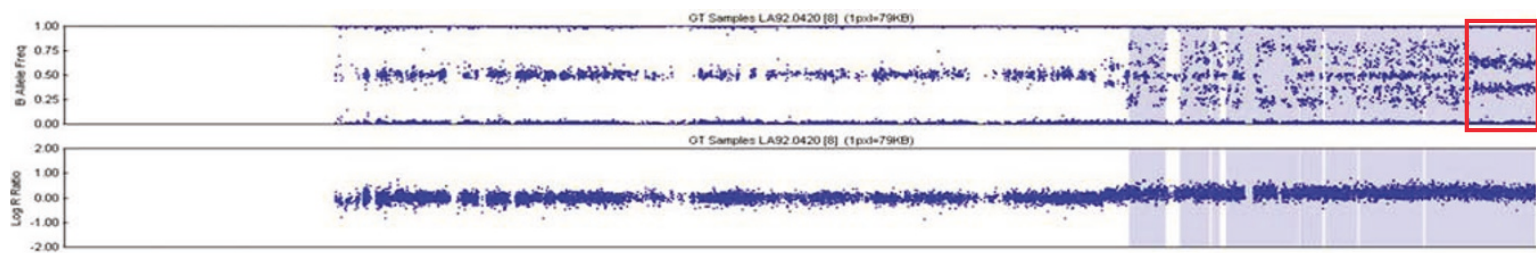

15

Figure 1 Identification of the sSMC in case 13 with GTG and FISH (a), MLPA (b) and SNP array analysis (c). a. GTG and FISH results: left: partial karyotype of 2 cells showing a normal chromosome 15 on the left and the SSMC on the right. Middle: partial metaphase after FISH with WCP15. Three chromosomes, both normal chromosomes 15 and the SSMC (arrow), are stained, provin Right: Partial metaphase after FISH with probe p80, located at 15q25-qter [37], showing 2 signals on both ends of the sSMC (arrow) indicative for (15). $\boldsymbol{b}$. MLPA results with the kits P036B (left) and P070 (right). The probes targeting ALDH1A3 and FL22604 (within red circle), respectively, both located at 15qtel, are clearly elevated but below 1.6 indicating 3 copies of both genes instead of four on the sSMC. c. HumanCytoSNP-12 result. Only chromosome 15 is depicted. The upper part shows the B-allele frequency (BAF) and the lower part shows the Log2 intensity along chromosome 15. Based on BAF (absence of a BAF of 0.5 at $15 \mathrm{q} 26.3$ while a meiotic origin is likely due to the presence of a BAF of 0.5 in a large part of the SSMC, indicating the presence of a third haplotype) and Log2 ratio (indicating 3 copies of the most distal end of 15q), the MLPA result of a trisomy at the distal q-arm at $15 \mathrm{q} 26.3$, is confirmed.

own calculated cut off values (table 2) with relative probe signals of the involving probes above the normal cut off values in all kits.

\section{Unique sequence negative sSMC}

The unique sequence negative sSMC (cases 2, 8-10, 1519, 26-30) all showed normal MLPA results with relative probe signals between the normal cut off values 0.7 and
1.3 confirming GTG/FISH results. There were no false positive cases.

\section{Discussion}

sSMC, when detected with conventional cytogenetic banding techniques, are still a problem as they often are too small or without a specific banding pattern to be considered for their chromosomal origin by traditional 
A
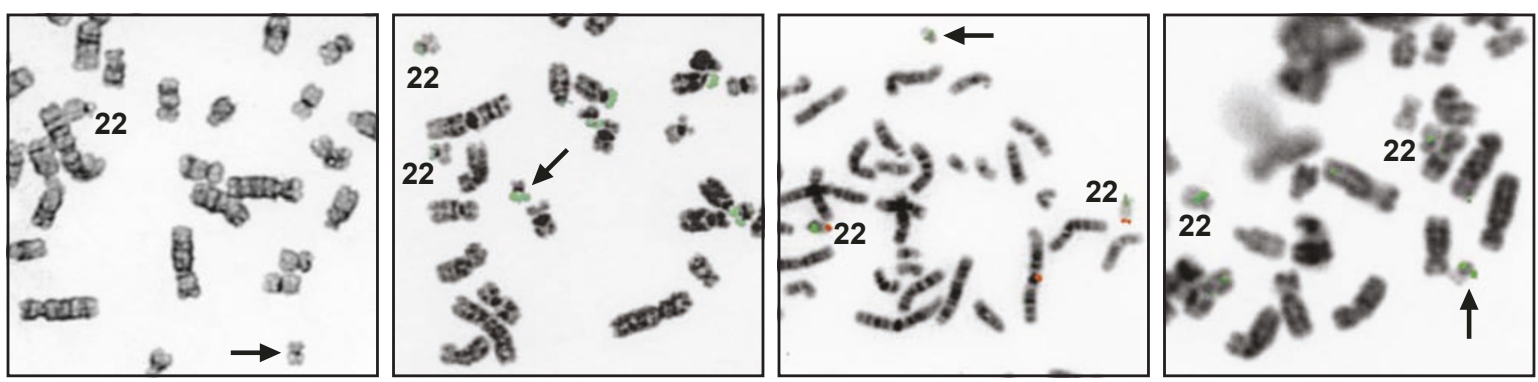

B
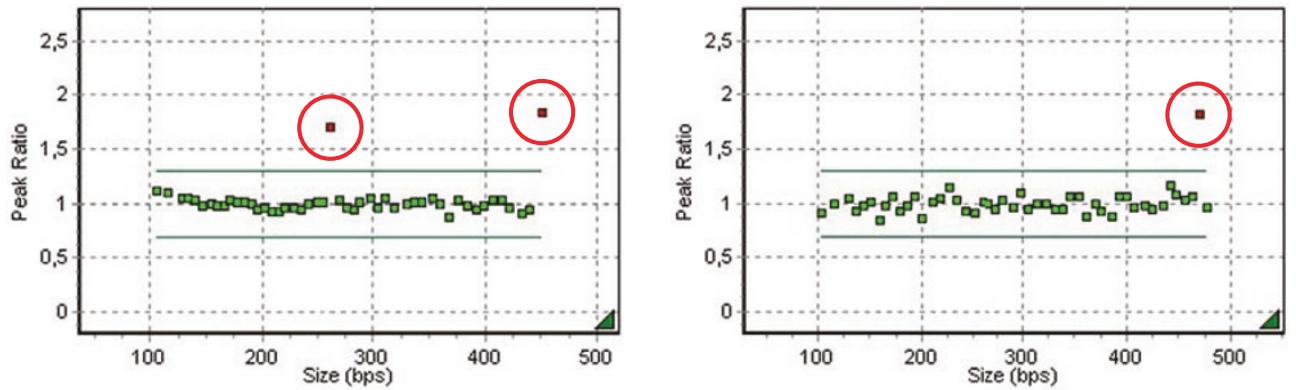

C

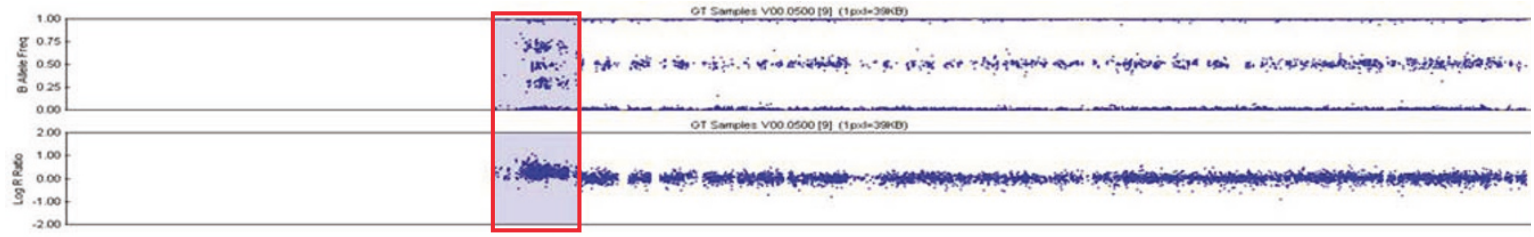

Figure 2 Identification of the familial sSMC in case 25: GTG and FISH (a), MLPA (b) and HumanCytoSNP-12 (c) results. a. Left. GTG partial metaphase showing the SSMC (arrow). 2 partial metaphase after FISH with the ribosomal DNA probe r521, showing on signal on the SSMC (arrow) and on the short arm of chromosomes. 3 and 22qtel probe (red) showing only one centromere signal and no 22qtel rel picture s. SMC (arrow). Both normal chromosomes 22 are positive with 22cen as well as with 22qtel probe. Right: partial metaphase after FISH with a Cat Eye Syndrome critical region probe $102 \mathrm{D} 10$ showing one signal on the SSMC (arrow) and on normal chromosomes 22. b. MLPA results with centromere kit P182 (left) en telomere kit P070 (right). The relative probe signals of the sequences targeting CECR1 and SLC25A18 in P182 and IL17R in P070 (in red circle) are clearly > 1.6 indicating 4 copies of these sequences on the SSMC. c. HumanCytoSNP-12 result. Only chromosome 22 is depicted. The upper part shows the Ballele frequency (BAF) and the lower part shows the Log R Ratio along chromosome 22. Based on the BAF (presence of a BAF of 0.5 in at least a part of the maternally inhereted SSMC, indicating the presence of a meiotic tetrasomy), the MLPA result of a partial tetrasomy 22q11, is confirmed.

banding techniques. Therefore, molecular cytogenetic techniques are often needed for further characterisation. Since the phenotypic consequences of a sSMC will greatly depend on its genetic content and chromosomal origin, it is of particular clinical importance to rapidly distinguish unique sequence-negative from unique sequence-positive sSMC because the former are less likely to be associated with an abnormal fetal outcome.
For a collection of all available reported sSMC cases, see the sSMC database [22].

Different papers describe the use of genomic array analysis for identification of sSMC $[15,16,23,24]$. The big advantage of this technique is that the exact chromosomal content of the unique-sequence positive sSMC can be determined in one reaction, although targeted FISH is often used following an abnormal array result and is 
sometimes necessary to determine the structure of the sSMC [24]. However, genomic array analysis is labour intensive, time-consuming and expensive. The use of the MLPA technique for characterisation of some specific sSMC has already been described in postnatal cytogenetics [25-28]. In this paper, we show that MLPA with centromere and telomere kits may be a quick initial approach for sSMC characterisation in prenatal diagnosis when time is limited. From every AF sample that we receive in our laboratory $4 \mathrm{ml}$ is used for direct DNA isolation. As soon as a sSMC is found, this DNA can be used for MLPA and results are available within less than 24 hours. In case of a positive result, targeted FISH and/ or array on (un)cultured AF cells may be used for confirmation and further identification. However, as with array analysis, MLPA will give normal results in case of an unique sequence-negative sSMC or in case of low level mosaicism [16]. Therefore, other techniques such as cenM-FISH [8] or sequential targeted FISH [29], although labour-intensive and frequently time-consuming, will be necessary for determining the chromosomal origin. Since such a sSMC most probably does not contain euchromatin, in the meanwhile, the parents can be karyotyped after reassurance.

Despite the development of molecular techniques for sSMC identification, conventional staining techniques are still valuable. Since $35 \%$ of the marker chromosomes with a known chromosomal origin are derived from chromosome 15 [30], the first thing to do in case of a satellited sSMC is a DA-DAPI staining. If positive, targeted FISH with chromosome 15 specific probes can be applied for further identification. If negative, FISH with a $13 / 21$ and $14 / 22$ centromere probe in conjunction with subcentromere probes for these 4 chromosomes can quickly elucidate the chromosomal content of the sSMC. In case of a non-satellited sSMC, MLPA might be a rapid and rather non-expensive technique for distinguishing between an unique sequence-positive and -negative sSMC.

The centromere kits P181 and P182 are presented by MRC Holland as kits for identification of sSMC. However, we recommend using the telomere kits in addition to these centromere kits for sSMC identification for three reasons. Firstly, by using only the centromere kits, the neo(12) and neo(15) would both have been missed. This type of sSMC, first described by Blennow [31] is rare. Up till now about $\sim 90$ neocentric acentric marker chromosomes have been described in patients with idiopathic mental retardation but also in cancer cells $[32,33]$. Secondly, the sSMC in cases 7 and 11 could be correctly identified as being unbalanced translocations by using centromere concomitant with telomere kits. Although rare, this type of sSMC, the so-called unique complex sSMC which are derived from more than one chromosome, may be underdiagnosed as suggested by Trifonov et al. [34], and MLPA with centromere and telomere kits may enhance their detection rate. And finally, since most sSMC are derived from the acrocentric chromosomes, the simultaneous use of centromere and telomere kits allows for more markers to be tested in the subcentromeric region since the telomere kits also contain probes in the proximal long arm of the acrocentric chromosomes instead of a specific short arm subtelomere probe which they lack.

In 5/6 mosaic cases with the level of mosaicism determined in cultured cells, DNA isolated from uncultured AF cells was used for MLPA hampering the interpretation of the results. For instance, normal MLPA results in cases 18 and 19 are most probably explained by absence of unique sequences on both sSMC. However, due to low-level mosaicism at least in the AF cell cultures and therefore probably also in the uncultured AF cells used for MLPA, a normal result caused by lowlevel mosaicism can never be excluded. It is known that discrepancies may exist concerning mosaicism level between cultured and uncultured AF cells with the level often being higher in uncultured cells since these are not subjected to selection, mostly in favour of normal cells as seen in cell cultures. However, the reverse has also been observed in some cases of tissue specific mosaicism if the contribution of the affected organ or organsystem to the total AF cell population is small [35], but also in cases of generalised mosaicism [36]. From this experience, we learned that it is important to make FISH-slides at the time of DNA isolation necessary for determination of the level of mosaicism in the DNA sample enabling a proper interpretation of molecular results.

In cases 13 and 25 we show that the use of molecular techniques such as MLPA and array analysis may show that some sSMC are much more complex than initially thought on the basis of conventional banding techniques and FISH. At the moment we are performing further FISH studies in order to elucidate the exact structure of the sSMC in both cases. Tsuchya et al. [24] already published the uncoverage of unexpected complexity in the form of complex rearrangements of some sSMC when they used array CGH. This will ultimately lead to a more accurate sSMC-phenotype correlation which is important for proper counselling of the prospective parents when the sSMC is found prenatally.

\section{Conclusion}

In this paper we show that MLPA with centromere (P181 and P182)-and telomere (P036B and P070)-kits allow for the rapid differentiation between unique sequence positive and negative sSMC. As compared to multicolour FISH techniques and microarray analysis, MLPA is a 
rather non-expensive and easy to perform technique in most clinical cytogenetic laboratories for the rapid elucidation of the harmfulness of a prenatally detected sSMC with results available within 24 hours.

\section{Additional material}

Additional file 1: Supplemental Table. 29 prenatal cases with a SSMC indication, SSMC identification with conventional staining and FISH techniques, positive or negative for euchromatin and final karyotype.

\section{Acknowledgements}

The authors wish to thank Dr. H. Beverloo for performing SKY in case 19, the colleagues from the postnatal cytogenetic laboratory for performing parental studies and T. de Vries Lentsch for his contribution to both figures. Bert Eussen is acknowledged for the development of many FISH probes used for identification of SSMC.

\section{Authors' contributions}

DVO coordinated the study and wrote the paper. MB performed the MLPA and microarray analyses. PN performed cytogenetic and FISH analyses. MIS, DVO, GH and R-JHG were responsible for the final (molecular) cytogenetic diagnoses and reports. GH and DVO studied the literature. R-JHG coördinated the genetic counselling of the parents. All authors read and approved the manuscript.

\section{Competing interests}

The authors declare that they have no competing interests.

Received: 15 December 2010 Accepted: 14 January 2011

Published: 14 January 2011

\section{References}

1. Sachs ES, Van Hemel JO, den Hollander JC, Jahoda MGJ: Marker chromosomes in a series of 10000 prenatal diagnoses. Cytogenetic and follow-up studies. Prenat Diagn 1987, 7:81-89.

2. Blennow E, Nielsen KB, Telenius H, Carter NP, Kristoffersson U, Holmberg E, Gillberg C, Nordenskjöld M: Fifty probands with extra structurally abnormal chromosomes characterized by fluorescence in situ hybridization. Am J Med Genet 1995, 55(1):85-94.

3. Müller-Navia J, Nebel A, Schleiermacher E: Complete and precise characterization of marker chromosomes by application of microdissection in prenatal diagnosis. Hum Genet 1995, 96(6):661-667.

4. Brøndum-Nielsen K, Mikkelsen M: A 10-year survey, 1980-1990, of prenatally diagnosed small supernumerary marker chromosomes, identified by FISH analysis. Outcome and follow-up of 14 cases diagnosed in a series of 12,699 prenatal samples. Prenat Diagn 1995, 15(7):615-619.

5. Hsu LY, Yu MT, Richkind KE, Van Dyke DL, Crandall BF, Saxe DF, Khodr GS, Mennuti M, Stetten G, Miller WA, Priest JH: Incidence and significance of chromosome mosaicism involving an autosomal structural abnormality diagnosed prenatally through amniocentesis: a collaborative study. Prenat Diagn 1996, 16(1):1-28

6. Kotzot D: Supernumerary marker chromosomes (SMC) and uniparental disomy (UPD): coincidence or consequence? J Med Genet 2002, 39(10):775-778.

7. Liehr $\mathrm{T}$, Weise $\mathrm{A}$ : Frequency of small supernumerary marker chromosomes in prenatal, newborn, developmentally retarded and infertility diagnostics. Int J Mol Med 2007, 19(5):719-731.

8. Nietzel A, Rocchi M, Starke H, Heller A, Fiedler W, Wlodarska I, Loncarevic IF, Beensen $\mathrm{V}$, Claussen U, Liehr T: A new multicolor-FISH approach for the characterization of marker chromosomes: centromere-specific multicolor-FISH (cenM-FISH). Hum Genet 2001, 108(3):199-204.

9. Starke H, Nietzel A, Weise A, Heller A, Mrasek K, Belitz B, Kelbova C, Volleth M, Albrecht B, Mitulla B, Trappe R, Bartels I, Adolph S, Dufke A, Singer S, Stumm M, Wegner RD, Seidel J, Schmidt A, Kuechler A, Schreyer I,
Claussen U, von Eggeling F, Liehr : Small supernumerary marker chromosomes (SMC's): genotype-phenotype correlation and classification. Hum Genet 2003, 114(1):51-67.

10. Liehr T, Starke H, Heller A, Kosyakova N, Mrasek K, Gross M, Karst C, Steinhaeuser U, Hunstig F, Fickelscher I, Kuechler A, Trifonov V, Romanenko SA, Weise A: Multicolor fluorescence in situ hybridization (FISH) applied to FISH-banding. Cytogenet Genome Res 2006, 114(34):240-244

11. Engelen JJM, Albrechts JCM, Hamers AJH, Geraedts JPM: A simple and efficiënt method for microdissection and microFISH. J Med Genet 1998, 35:265-268.

12. de Pater JM, Kroes HY, Verschuren M, van Oppen AC, Albrechts JC, Engelen JJ: Mosaic trisomy (8)(p22 -> pter) in a fetus caused by a supernumerary marker chromosome without alphoid sequences. Prenat Diagn 2005, 25(2):151-155.

13. Schröck E, du Manoir S, Veldman T, Schoell B, Wienberg J, FergusonSmith MA, Ning Y, Ledbetter DH, Bar-Am I, Soenksen D, Garini Y, Ried T: Multicolor spectral karyotyping of human chromosomes. Science 1996, 273:494-497.

14. Speicher MR, Gwyn Ballard S, Ward DC: Karyotyping human chromosomes by combinatorial multi-fluor FISH. Nat Genet 1996, 12(4):368-375.

15. Ballif BC, Hornor SA, Sulpizio SG, Lloyd RM, Minier SL, Rorem EA, Theisen A, Bejjani BA, Shaffer LG: Development of a high-density pericentromeric region $B A C$ clone set for the detection and characterization of small supernumerary marker chromosomes by array CGH. Genet Med 2007, 9(3):150-162.

16. Baldwin EL, Lee JY, Blake DM, Bunke BP, Alexander CR, Kogan AL, Ledbetter $\mathrm{DH}$, Martin $\mathrm{CL}$ : Enhanced detection of clinically relevant genomic imbalances using a targeted plus whole genome oligonucleotide microarray. Genet Med 2008, 10(6):415-429.

17. Karaman B, Aytan M, Yilmaz K, Toksoy G, Onal EP, Ghanbari A, Engur A, Kayserili H, Yuksel-Apak M, Basaran S: The identification of small supernumerary marker chromosomes; the experiences of 15,792 fetal karyotyping from Turkey. Eur J Med Genet 2006, 49(3):207-14.

18. Schweitzer D, Ambros P, Andrle M: Modification of DAPI banding on human chromosomes by prestainig with a DNA binding oligopeptide, distamycin A. Exp Cell Res 1978, 111:327-332.

19. Knight SJ, Lese CM, Precht KS, Kuc J, Ning Y, Lucas S, Regan R, Brenan M, Nicod A, Lawrie NM, Cardy DL, Nguyen H, Hudson TJ, Riethman HC, Ledbetter DH, Flint J: An optimized set of human telomere clones for studying telomere integrity and architecture. Am J Hum Genet 2000, 67:320-332.

20. Smidt-Jensen S, Christensen B, Lind AM: Chorionic villus culture for prenatal diagnosis of chromosome defects: reduction of the long-term cultivation time. Prenat Diagn 1989, 9(5):309-319.

21. Van Opstal D, Boter M, de Jong D, van den Berg C, Brüggenwirth $H T$, Wildschut HIJ, de Klein A, Galjaard R-JH: Rapid aneuploidy detection with multiplex ligation-dependent probe amplification: a prospective study of 4000 amniotic fluid samples. Eur J Hum Genet 2009, 17:112-121.

22. Liehr T: Small supernumerary marker chromosomes database. [http://www.med.uni-jena.de/fish/sSMC/OOSTART.htm]

23. Vermeesch JR, Melotte C, Salden I, Riegel M, Trifnov V, Polityko A, Rumyantseva N, Naumchik I, Starke H, Matthijs G, Schinzel A, Fryns JP, Liehr T: Tetrasomy 12pter-12p13.31 in a girl with partial Pallister-Killian syndrome phenotype. Eur J Med Genet 2005, 48(3):319-327.

24. Tsuchiya KD, Opheim KE, Hannibal MC, Hing AV, Glass IA, Raff ML, Norwood T, Torchia BA: Unexpected structural complexity of supernumerary marker chromosomes characterized by microarray comparative genomic hybridization. Mol Cytogenet 2008, 1:7.

25. Medne L, Zackai EH, Emanuel BS: Emanuel Syndrome. In GeneReviews [Internet]. Edited by: Pagon RA, Bird TC, Dolan CR, Stephens K. Seattle (WA): University of Washington, Seattle; 1993:; [updated 2010 May 11].

26. Pacanaro AN, Christofolini DM, Kulikowski LD, Belangero SI, da Silva Bellucco FT, Varela MC, Koiffmann CP, Yoshimoto M, Squire JA, Schiavon AV, Heck B, Melaragno MI: A rare case of trisomy 15pter-q21.2 due to a de novo marker chromosome. Am J Med Genet A 2010, 152A(3):753-758.

27. Hoppman-Chaney NL, Dawson DB, Nguyen L, Sengupta S, Reynolds K McPherson E, Velagaleti G: Partial hexasomy for the Prader-WilliAngelman syndrome critical region due to a maternally inherited large supernumerary marker chromosome. Am J Med Genet A 2010, 152A(8):2034-2038 
28. Kleefstra T, de Leeuw N, Wolf R, Nillesen WM, Schobers G, Mieloo H, Willemsen M, Perrotta CS, Poddighe PJ, Feenstra I, Draaisma J, van Ravenswaaij-Arts CM: Phenotypic spectrum of 20 novel patients with molecularly defined supernumerary marker chromosomes 15 and a review of the literature. Am J Med Genet A 2010, 152A(9):2221-2229.

29. Cotter PD, Drexler K, Corley AL, Covert SM, Moland JS, Govberg IJ, Norton ME: Prenatal diagnosis of minute supernumerary marker chromosomes. Gynecol Obstet Invest 2005, 60(1):27-38.

30. Crolla JA, Youings SA, Ennis $S$, Jacobs PA: Supernumerary marker chromosomes in man: parental origin, mosaicism and maternal age revisited. Eur J Hum Genet 2005, 13(2):154-160.

31. Blennow E, Telenius $H$, de Vos D, Larsson C, Henriksson P, Johansson $O$, Carter NP, Nordenskjöld M: Tetrasomy 15q: two marker chromosomes with no detectable alpha-satellite DNA. Am J Hum Genet 1994, 54(5):877-883.

32. Murmann AE, Conrad DF, Mashek H, Curtis CA, Nicolae Rl, Ober C, Schwartz S: Inverted duplications on acentric markers: mechanism of formation. Hum Mol Genet 2009, 18(12):2241-2256.

33. Liehr T, Utine GE, Trautmann U, Rauch A, Kuechler A, Pietrzak J, Bocian E, Kosyakova N, Mrasek K, Boduroglu K, Weise A, Aktas D: Neocentric small supernumerary marker chromosomes (SSMC)-three more cases and review of the literature. Cytogenet Genome Res 2007, 118(1):31-37.

34. Trifonov V, Fluri S, Binkert F, Nandini A, Anderson J, Rodriguez L, Gross M, Kosyakova N, Mkrtchyan H, Ewers E, Reich D, Weise A, Liehr T: Complex rearranged small supernumerary marker chromosomes (sSMC), three new cases; evidence for an underestimated entity? Mol Cytogenet 2008, 1:6.

35. Van Opstal D, van den Berg C, Galjaard RJ, Los FJ: Follow-up investigations in uncultured amniotic fluid cells after uncertain cytogenetic results. Prenat Diagn 2001, 21(2):75-80.

36. Veenma DCM, Beurskens LWJE, Douben J, Eusen B, Noomen P, Govaerts L, Grijseels EW, Lequin MH, de Krijger RR, Tibboel D, de Klein A, Van Opstal D: Comparable low-level mosaicism in affected and non affected tissue of a complex CDH patient. PLOS ONE 2010, 5(12):e15348.

37. Heisterkamp N, Groffen J, Stephenson JR, Spurr NK, Goodfellow PN, Solomon E, Carritt B, Bodmer WF: Chromosomal localization of human cellular homologues of two viral oncogenes. Nature 1982, 299(5885):747-749.

38. Cockwell AE, Jacobs PA, Crolla JA: Distribution of the D15Z1 copy number polymorphism. Eur J Hum Genet 2007, 15:441-445.

39. Srebniak M, Noomen $P$, dos Santos $P$, Halley D, van de Graaf R, Govaerts $L$, Wouters C, Galjaard RJ, Van Opstal D: An incomplete trisomy 3 rescue resulting in a marker chromosome and UPD(3)-difficulties in interpretation. Prenat Diagn 2008, 28(10):967-970.

40. Van Opstal D, Eussen HJ, Van Hemel JO, Sachs ES: Application of fluorescent in situ hybridization for 'de novo' anomalies in prenatal diagnosis. Prenat Diagn 1993, 13(9):825-832.

doi:10.1186/1755-8166-4-2

Cite this article as: Van Opstal et al:: Multiplex ligation dependent probe amplification (MLPA) for rapid distinction between unique sequence positive and negative marker chromosomes in prenatal diagnosis. Molecular Cytogenetics 2011 4:2.

\section{Submit your next manuscript to BioMed Central and take full advantage of:}

- Convenient online submission

- Thorough peer review

- No space constraints or color figure charges

- Immediate publication on acceptance

- Inclusion in PubMed, CAS, Scopus and Google Scholar

- Research which is freely available for redistribution

Submit your manuscript at www.biomedcentral.com/submit
Biomed Central 